\title{
PENDIDIKAN MORAL PESERTA DIDIK MELALUI IMPLEMENTASI TATA TERTIB SEKOLAH DASAR NEGE RI IN PRES BUMI BAHARI KECAMATAN PALU BARAT
}

\author{
Retolia \\ Sitti Nadirah
}

\begin{abstract}
Abstrad:
An Efforts to improve the morality of leamers are alvays conducted in education Educational institutions are morally ddigated to increse personality dadqpment of their students SDN Inpres Bumi Bahan Kec Palu Barat through the implementation of schod nules, intends to form the dharader of leames. This dramstance is the basis of this reserch This research based on descriptive qualitative mothook. The Saurce of data dotained fromprinipals, teaches, and Lemers. This rearch used varieties mthods such as doservation, interviens, and doomentations in data colleting process Furthemore, data that has been netted, analyzed using data reeluction teetniques, data display, and data verification The results of the stury conduded that theapplication of shod nules can shape the behavior of leamers to be a good persomality. The behavior of leames is dreted tovards moral leamer. The process of dharader building of leamers finds some bamiers because leamers have a different undestanding of schod nules arder. In addition, many students have a strong influence of the habits they bing from their homes, so they arend familiar with thenles st by their schod.
\end{abstract}

Keguards Pendidikan Moral, Tata Tertib, Perilaku peserta didik 


\section{Pendahuluan}

Sejak manusia menghendaki kemajuan dalam kehidupan, maka sejak itu timbul gagasan untuk melakukan pengalihan, pelestarian dan pengembangan kebudayaan melalui pendidikan.Oleh karena itu, pendidikan di dalam masyarakat senantiasa menjadi perhatian utama dalam rangka memajukan kehidupan generasi yang sejalan dengan tuntutan, perkembangan dan kemajuan masyarakat dari zaman ke zaman.

Manusia adalah subjek dan objek pendidikan, manusia dewasa yang berkebudayaan adalah subjek pendidikan dalam arti yang bertanggungjawab menyelenggarakan pendidikan.Mereka berkewajiban secara moral atas perkembangan pribadi anak-anak mereka, generasi penerus mereka, manusia dewasa yang berkebudayaan terutama yang berpotensi keguruan (pendidikan) bertanggungjawab formal untuk melaksanakan misi pendidikan sesuai dengan tujuan dan nilai-nilai yang dikehendaki masyarakat bangsa itu. ${ }^{1}$

Sejalan dengan itu, pendidikan tidak akan bisa berjalan dengan lancar tanpa adanya peserta didik.Peserta didik itulah nantinya yang akan berkembang setelah dewasa. Peserta didik adalah suatu bahagian yang tidak terpisahkan, bahkan merupakan suatu objek dari pendidikan. Kegiatan pendidikan mustahil berlangsung tanpa adanya objek atau anak didik, anak didik merupakan salah satu unsur terpenting dari faktor yang paling menentukan dalam pendidikan, karena hampir seluruh kegiatan pendidikan diarahkan untuk membantu, membimbing dan mendorong peserta didik untuk mencapai tujuan pendidikan dengan memanfaatkan secara selektif dan efektif semua perilaku didik yang berlangsung dalam interaksi dan komunikasi, edukatif antara pendidikan dan peserta didik. D engan kata lain pendidikan dengan peserta didik merupakan suatu kesatuan yang tak terpisahkan dalam pendidikan.

Namun demikian, cita-cita atau harapan untuk menjadikan peserta didik menjadi berhasil dan mampu menjadi generasi penerus tidak akan berhasil manakala peserta didik tidak memiliki perilaku atau moral yang baik. Bahkan dapat dikatakan bahwa indikator keberhasilan proses pendidikan pada semua jenjang dapat

${ }^{1}$ A. Rahman Getteng, Pendidikan Islam Dalam Pembangunan, (Ujung Pandang : Yayasan al-Ahkam, 1997), h. 11 
dilihat pada out put pendidikan itu sendiri yang berupa peserta didik yang memiliki moral yang sangat baik. Hanya saja, dalam menanamkan moralitas kepada peserta didik merupakan tantangan tersendiri.Hal ini disebabkan jenjang pendidikan seseorang tidaklah selamanya berbading lurus dengan moralitas yang dimilikinya. Artinya, tidak ada jaminan bahwa seseorang yang memiliki jenjang pendidikan yang tinggi secara otomatis akan memiliki moralitas yang tinggi pula. Di sinilah letak pentingnya pendidikan moral ditanamkan pada diri peserta didik.Utamanya peserta didik yang masih berada pada jenjang pendidikan dasar.

Oleh karena itu, setiap lembaga pendidikan harus mengemban tugas untuk menanamkan nilai-nilai moral kepada peserta didiknya. A palagi disadari sepenuhnya bahwa moral tidak hanya sekedar diajarkan kepada peserta didik, akan tetapi harus dibiasakan kepada mereka, sehingga moralitas tersebut inheren dengan dirinya. Di sinilah Imam Al-Ghazali menegaskan bahwa perilaku atau ahklak pada diri seseorang merupakan perbuatan yang dilakukan secara spontanitas tanpa melalui pertimbanganpertimbangan untuk melakukannya.Apa yang dikemukakan oleh Imam Al-Ghazali tersebut, tidak akan pernah bisa terwujud manakala tidak dilakukan melalui pembiasaan pada diri seseorang.

Jika dikaitkan dengan pendidikan, maka dapat dipahami bahwa moralitas pada diri peserta didik hanya dapat dilakukan melalui pembiasaan untuk melakukan hal-hal yang telah terpola sedemikian rupa. Lewat pembiasaan yang baik inilah, peserta didik diharapkan akan melakukan hal-hal dengan tanpa pertimbangan.

Dalam konteks pendidikan dasar, selain melalui proses pembelajaran, pola pembiasaan moralitas yang baik yang dapat dilakukan adalah pengetatan pelaksanaan tata tertib sekolah. Pelaksanaan tata tertib yang dimaksudkan adalah hal-hal baik yang harus dilaksanakan dan dipatuhi oleh setiap peserta didik ; mulai mereka berada di gerbang sekolah sampai mereka meninggalkan sekolah. Melaksanakan tata tertib secara disiplin dan konsisten dengan sendirinya akan memberikan pembiasaan perilaku baik pada diri peserta didik. A palagi Undang-Undang Nomor 20 Tahun 2003 yang menyatakan bahwa tujuan pendidikan adalah :

untuk berkembangnya potensi peserta didik agar menjadi manusia yang beriman dan bertaqwa kepada Tuhan Yang Maha Esa, berakhlak mulia, sehat, berilmu, cakap, kreatif, 
mandiri, dan menjadi warga negara yang demokratis serta bertanggungjawab. ${ }^{2}$

Berdasarkan hal tersebut, dapat dipahami bahwa tujuan pendidikan yang ingin dicapai sangatlah mulia.O leh karena itu, semua lembaga pendidikan, baik lembaga pendidikan formal maupun nonformal senantiasa mengacu kepada pencapaian tujuan tersebut, termasuk dalam hal ini Sekolah Dasar Negeri Inpres Bumi Bahari Kecamatan Palu Barat.Namun demikian, disadari sepenuhnya bahwa alat untuk untuk mencapai tujuan tersebut tidaklah cukup hanya dengan ketersediaan fasilitas belaka, melainkan juga termasuk tingkat ketaatan peserta didik terhadap segala peraturan yang dapat menjamin ke arah pencapaian tujuan dimaksud.

Untuk menjamin sistematika pembahasan dalam penelitian ini, maka penulis memberikan batasan masalah sebagai berikut :

a. Bagaimana pelaksanaan pendidikan moral peserta didik melalui implementasitata tertib Sekolah Dasar Negeri Inpres Bumi Bahari Kecamatan Palu Barat?

b. Bagaimana hambatan-hambatan guru dalam pelaksanaan pendidikan moral peserta didik melalui implementasitata tertib sekolah di Sekolah Dasar Negeri Inpres Bumi Bahari Kecamatan Palu Barat.

\section{Pembahasan}

Langeveld mengemukakan bahwa pendidikan ialah setiap usaha, pengaruh, perlindungan, dan bantuan yang diberikan kepada anak tertuju kepada pendewasaan anak itu, atau lebih tepat membantu anak agar cukup cakap melaksanakan tugas hidupnya sendiri.Pengaruh itu datangya dari orang dewasa (atau yang diciptakan oleh orang dewasa seperti sekolah, buku, putaran hidup sehari-hari, dan sebagainya) dan ditujukan kepada orang yang belum dewasa. ${ }^{3}$

${ }^{2}$ Departemen gama R.I. Direktoran Jendderal kelembagaan Agama Islam, Memahami Paradigma Baru Pendidikan Nasional Dalam UndangUndang SISDIKNAS (Jakarta : Ditjen Kelembagaan Agama Islam Depag, 2003) h. 37

${ }^{3}$ Hasbullah, Dasar-Dasar Ilmu Pendidikan, (Cet. I ; Jakarta: PT. Radja Grafindo Persada. 2005), h. IX 
Selain itu, John D ewey mengemukakan bahwa pendidikan adalah proses pembentukan kecakapan-kecakapan fundamental secara intelektual dan emosional kearah alam dan sesama manusia. ${ }^{4}$ Carter .V. Good dalam Hasbullah mengemukakan bahwa Pendidikan adalah : 1) seni, praktik, atau profesi sebagai pengajar; 2) Ilmu yang sistematis atau pengajaran yang berhubungan dengan prinsip dan metode-metode mengajar, pengawasan dan bimbingan murid dalam arti luas digantikan dengan istilah pendidikan. ${ }^{5}$

D ari beberapa pengertian atau batasan pendidikan yang diberikan para ahli tersebut, meskipun berbeda secara redaksional, namun secara esensial terdapat kesatuan unsur-unsur atau fakorfaktor yang terdapat didalamnya, yaitu pendidikan menunjukkan suatu proses bimbingan, tuntunan atau pimpinan yang didalamnya mengandung unsur-unsur seperti pendidik, anak didik, tujuan, dan sebagainya.

Memperhatikan batasan-batasan tersebut, ada beberapa pengertian dasar yang perlu dipahami, yaitu :

a. Pendidikan merupakan suatu proses terhadap anak didik berlangsung terus sampai anak didik mencapai pribadi dewasa susila, maka ia sepenuhnya mampu bertindak sediri bagi kesejahteraan hidupnya dan masyarakatnya.

b. Pendidikan merupakan perubahan manusiawi. Pendidikan lahir dari pergaulan antar orang dewasa dan orang yang belum dewasa dalam suatu kesatuan hidup. Kedewasaan diri merupakan tujuan pendidikan yang dicapai melalui perbuatan atau tindakan pendidikan.

c. Pendidikan merupakan hubungan antar pribadi pendidik dan anak didik. Dalam pergaulan terjadi kontak atau komunikasi antara masing - masing pribadi. Hubungan ini jika meningkat ketaraf pendidikan, maka menjadi hubungan antara pribadi pendidik dan pribadi si anak didik, yang pada akhirnya melahirkan tanggung jawab pendidikan dan kewibawaan pendidikan.

d. Tindakan atau perbuatan mendidik menuntun anak didik mencapai tujuan - tujuan tertentu, dan hal ini tampak pada perubahan - perubahan dalam diri anak didik.

${ }^{4}$ Ibid. h. 1

${ }^{5}$ Ibid.h. 4 
Secara historis, pendidikan jauh lebih tua dari ilmu pendidikan, sebab pendidikan telah ada sejak adanya manusia.Sedangkan ilmu pendidikan baru lahir kira-kira pada abad ke-19.Sebelum adanya ilmu pendidikan, manusia melakukan tindakan mendidik didasarkan atas pengalaman, intuisi dan kebijaksanaan.

Pembaharuan sistem pendidikan nasional dilakukan untuk memperbarui visi, misi, dan strategi pembangunan pendidikan nasional.Pendidikan nasional mempunyai visi terwujudnya sistem pendidikan nasional sebagai pranata sosial yang kuat dan berwibawa untuk memberdayakan semua warga Negara Indonesia berkembang menjadi manusia yang berkualitas sehingga mampu dan proaktif menjawab tantangan zaman yang selalu berubah.

\section{Pendidikan Moral}

Moralitas adalah kata yang sering digunakan untuk menunjukkan suatu tingkah laku manusia.Moral ini sendiri berarti baik buruk perbuatan dan kelakuan. ${ }^{68}$ Selanjutnya, perkataan moral diambil dari bahasa Latin moes, yaitu jamak dari mos yang berarti adat kebiasaan. ${ }^{7}$

Kata yang sepadan dan sering digunakan untuk menunjuk moral adalah budi pekerti.Pengertian budi pekerti mengacu pada pengertian bahasa Inggris, yang diterjemahkan sebagai moralitas. Moralitas mengandung beberapa pengertian antara lain: adat istiadat, sopan santun, dan perilaku. Namun, pengertian budi pekerti secara hakiki adalah perilaku.

Sementara itu, menurut draf kurikulum berbasis kompetensi, budi pekerti berisi nilai-nilai perilaku manusia yang akan diukur menurut kebaikan dan keburukannya melalui norma agama, norma hukum, tata karma dan sopan santun, norma budaya dan adat istiadat masyarakat. Budi pekerti akan mengidentifikasi perilaku positif yang diharapkan dapat terwujud dalam perbuatan, perkataan, pikiran, sikap, perasaan, dan kepribadian peserta didik. Budi pekerti berinduk pada etika atau filsafat moral.Secara etimologs, kata etika sangat dekat dengan moral. Etika berasal dari bahasa yunani ethos (jamak: ta tha) yang berarti adat kebiasaan.

\footnotetext{
${ }^{8}$ W.J.S. Poerwadarminta, Kamus Umum Bahasa Indonesia (Jakarta:Balai Pustaka,1982) h. 654

${ }^{7}$ Asmaran As., Pengantar Studi Akhlak Edisi Revisi (Cet. III ; Jakarta : Raja Grafindo Persada, 2002) h. 8
} 
Adapun moral berasal dari bahasa latinmos (jamak: mores) yang juga mengandung adat kebiasaan. ${ }^{8}$

Pendidikan moral berusaha untuk mengembangkan pola perilaku seseorang sesuai dengan kehendak masyarakatnya.Kehendak ini berwujud moralitas atau kesusilaan yang berisi nilai-nilai dan kehidupan yang berada dalam masyarakat.Karena menyangkut dua aspek inilah, yaitu nilai-nilai dan kehidupan nyata, maka pendidikan moral lebih banyak membahas masalah dilemma (seperti makan buas simalakama) yang berguna untuk mengambil keputusan moral yang terbaik bagi diri dan masyarakatnya.

Kalau kita menelaah kawasan nilai budaya dan menelaah tujuan kelembagaan sekolah, maka pengertian pendidikan moral di Indonesia dimaksudkan agar manusia menjadi bermoral, dan bukannya pendidikan tentang moral yang akan mengutamakan penalaran moral (moral reasaning dan pertumbuhan inteigensi sehingga seseorang bisa melakukan pilihan dan penilaian moral yang paling tepat. Di sinilah orang bisa saja tidak sependapat mengenai pendidikan tentang moral di Indonesia. ${ }^{9}$

Berdasarkan tujuan pendidikan nasional, yang tercantum dalam GBHN dan tujuan kelembagaan sekolah serta tujuan pendidikan moral yang diberikan pada tingkat sekolah dan perguruan tinggi, maka pendidikan moral di Indonesia adalah suatu program pendidikan (sekolah dan luar sekolah) yang mengorganisasikan dan menyederhanakan sumber-sumber moral dan disajikan dengan memperhatikan pertimbangan psikologis untuk tujuan pendidikan.

Menurut paham ahli pendidikan moral, jika tujuan pendidikan moral akan mengarahkan seseorang menjadi bermoral, yang penting adalah bagaimana agar seseorang dapat menyesuaikan diri dengan tujuan hidup bermasyarakat. Oleh karena itu, dalam tahap awal perlu dilakukan pengondisian moral (moral conditioning dan latihan moral (moral training untuk pembiasaan.

Seseorang yang berperilaku tidak sesuai dengan aturan dan moral yang dianggap baik pada saat itu harus dihukum. Keterampilan intelektual kurang dipentingkan dalam paham ini

8 Nurul Zuriah. Pendidikan Moral dan Budi Pekerti dalam Perspektif Perubahan.(Cet. II, Jakarta : Bumi Aksara, 2008), h. 17

${ }^{9}$ Ibid., h.21 
karena akan memperlambat seseorang dalam penyesuaian dirinya, paham ini bertujuan sebagai upaya untuk mengimbangi pesatnya. Artinya, paham ini beranggapan bahwa pendidikan moral adalah pengajaran tentang moral.

Pengertian moral dalam pendidikan moral di sini hampir sama saja dengan rasional, dimana penalaran moral dipersiapkan sebagai prinsip berpikir kritis untuk sampai pada pilihan dan penilain moral (moral dhiceandmaral judgment) yang dianggap sebagai pikiran dan sikap terbaiknya.

D alam menghadapi suatu masalah sosial dan moral, paham ini beranggapan bahwa seseorang harus dibantu untuk menggerakkan kemampuan intelektualnya, yaitu melakukan kegiatan berpikir yang sifatnya reflektif dengan menggunakan berbagai kegiatan berpikir knitis, analisis, sintetis, dan evaluative dengan juga merujuk pada orang yang lebih mengetahui, menggunakan intuisi dan akal sehat. Alasan yang dikemukakan oleh paham ini kedengarannya seperti biasa diterima semua orang terutama kalangan cendekiawan, tetapi dalam tahapan sesuatu bangsa yang reative masih muda, yang masih memerlukan pemantapan idedogy dan kesatuan gerak pembangunan seperti Negara Indonesia, kiranya tekanan dgjektifmasih diperlukan. ${ }^{10}$

Namun demikian, walaupun penalaran dan latihan moral dalam rangka intemalisas nilai moral yang akan dicapai agak intensif dilakukan, pada tingkat pendidikan tertentu hendaknya berbagai ilmu pengetahuan yang rdevan dengan moral patut ikut memperkaya pengertian moral di Indonesia. Hal ini dimaksudkan agar pengertian moral di Indonesia lebih luas pandangan dan harapannya.

Pemahaman mengenai arti pendidikan moral akan ikut menentukan isi pendidikan. Bagi pengikut paham yang mengartikan pendidikan moral untuk menjadikan seseorang bermoral, maka isi pendidikan merupakan pilihan yang beranggapan paling tepat untuk mengantarkan seseorang hidup bermasyarakat. Bahkan pendidikan yang diperkirakan tidak sesuai dengan tujuan moral tidak dimasukkan dalam kurikulum yang akan dibahas. Kalaupun terpaksa disebut dalam isi pelajaran maka bahan pelajaran itu disebut dosed ares yaitu bahan pelajaran yang tabu dan seet untuk dibicarakan, seperti yang berkenaan dengan masalah

${ }^{10}$ Ibid., h. 22 
ras, politik, kesukuan, dan lain sebagainya. Oleh sebab itu, pilihan isi pelajaran harus tersaring dan terseleksi secara ketat, yaitu bahan pelajaran yang sudah masuk dalam apa yang disebut publicalture

Bahan pelajaran tersebut sudah dianggap akan diterima oleh semua golongan atau pihak dan dianggap baik sebagai jembatan untuk mencapai tujuan pendidikan dan tujuan hidup bermasyarakat. D ari situlah kemudian disusun serangkaian pokokpokok isi pendidikan moral sebagai pedoman umum dalam mendidik moral.Serangkaian pokok isi pendidikan moral ini dianggap sebagai persyaratan djektif dari Negara sebagai organisasi puncak yang bertugas memelihara dan membina moral agar bisa mewujudkan tujuan hidup yang sudah ditetapkan.Bahaya dari penyusunan bahan seperti itu adalah pendidikan moral bisa membosankan dan kurang dihargai. ${ }^{11}$

\section{Pengembangan Moral}

Terhadap hukuman moral atau budi pekerti yang melahirkan pertentangan antara perlu dan tidak perlu akhirnya memunculkan tiga jenis teori hukuman moral budi pekerti yang oleh Brubacher masing-masing disebut teori balas dendam, teori perlindungan, dan teori pendidikan. ${ }^{12}$

a. Teori balas dendam. Teori balas dendam mengandung prinsip bahwa hukuman merupakan jenis balas dendam. Kerugian yang diderita orang lain dapat dihapus atau diganti dengan kerugian yang sama terhadap orang yang berbuat pelanggaran. Prinsip ini didasarkan atas ketentuan hukum moral zaman kuno yang menyatakan: "utang darah diganti darah". Teori ini juga didukung oleh bukti bahwa seseorang melakukan pelanggaran atau kejahatan dilandasi oleh penuh kesadaran. Seorang anak tahu bahwa tindakan yang dikehendakinya salah, namun tetap dilakukan meskipun ia mengetahuinya. Ia melakukannya karena penuh kedengkiaan yang telah direncanakan sebelumnya. Untuk menghadapi masalah tersebut, hukum moral harus menunjukkan fungsinya dengan menjatuhkan hukuman yang memadai sebagai penebus dosa.

b. Teori Perlindungan. Teori ini berisi ketentuan bahwa hukuman dapat dijatuhkan kepada seseorang untuk melindungi masyarakat dengan memberi contoh hukuman kepada si

\footnotetext{
${ }^{11}$ Ibid., h. 23

${ }^{12}$ Ibid., h. 4
} 
pelanggar. Hukuman ini tidak bermaksud menghapus kesalahan si pelanggar, melainkan lebih meyakinkan masyarakat untuk melawan pelanggaran sejenis bagi kepentingan hidup yang aman dan damai. Perilaku si pelanggar yang antisocial merupakan ancaman bagi keberadaan kewenangan dan wibawa kelompok atau masyarakat bahkan sekolah. Kelemahan teori ini adalah balas dendam sebagai dorongan untuk menghukum seseorang mungkin terlalu keras sehingga mengakibatkan orang yang dihukum malahan sakit hati dan bukannya memperoleh peringatan.

c. Teori Pendidikan. Teori ini umumnya dianut oleh sekolah. Teori pendidikan memandang bahwa kedua teori di atas mengandung kelemahan, yaitu terlalu buruk atau keras sehingga meyingkirkan aspek rehabilitasi anak yang keras kepala. Prinsip yang dianut oleh teori ini adalah hukuman tidak boleh dijatuhkan kepada seseorang jika tidak mengandung upaya membina atau mendidik kembali sesuai dengan kehendak masyarakat yang berharap moral harus ditegakkan dalam masyarakat. Si pelanggar harus diberi kesempatan untuk melihat diri sendiri mengenai perbuatannya, seperti orang lain melihat dirinya. Namun, jika ia gagal dalam memahami diri dan gagal pula memahami aturan moral, maka hukuman yang dijalaninya juga berarti mengalami kegagalan.

Ruang lingkup pengembangan moral secara garis besar dapat dikelompokkan dalam tiga hal nilai akhlak yaitu: a) Akhlak terhadap Tuhan yang Maha $\mathrm{Esa}^{13}$, b) Akhlak terhadap sesama manusia, dan c) Akhlak terhadap lingkungan.

\section{Tata Tertib Sekolah}

Ketika berbicara tentang tata tertib, maka asosiasi pemikiran akan tertuju pada kedisiplinan. Artinya, di mana saja tata tertib tersebut sekolah diterapkan, maka di situ akan sarat dengan nilai-nilai kedisiplinan, termasuk di dalamnya lembaga persekolahan.

Disiplin merupakan hal penting yang harus ditanamkan pada anak didik di sekolah sedini mungkin.Disiplin ini sendiri berarti latihan batin dan watak dengan maksud supaya segala perbuatannya mentaati tata tertib (di sekolah atau di meliter).D apat

\footnotetext{
${ }^{13}$ Ibid., h. 29-32.
} 
pula berarti ketaatan pada aturan dan tata tertib. ${ }^{14} \mathrm{Hal}$ ini disebabkan karena sekolah merupakan tempat utama untuk melatih dan memahami pentingnya disiplin dalam kehidupan sehari-hari. Melalui tata tertib sekolah yang senantiasa diterapkan sehari-hari kepada para anak didik, maka anak didik dengan sendirinya akan terbiasa untuk berdisiplin. Sekolah harus memiliki sejumlah tata tertib yang harus disosialisasikan dan dicontohkan kepada para anak didik serta dilaksanakan secara terus menerus. Tata tertib sekolah yang dimaksud tersebut meliputi :

1. Tata tertib setelah masuk ke sekolah.

2. Tata tertib sebelum masuk kelas.

3. Tata tertib di dalam kelas.

4. Tata tertib ketika istirahat.

5. Tata tertib ketika pulang dari sekolah. ${ }^{15}$

Kelima komponen tata tertib sekolah tersebut, dijabarkan pada setiap lembaga pendidikan (sekolah dasar) sesuai dengan situasi dan kondisi daerah masing-masing.

Moralitas yang baik pada diri peserta didik akan melekat melalui pembiasaan yang dilakukan secara konsisten. Salah satu pembiasaan melakukan hal-hal yang di Sekolah D asar Inpres Bumi Bahari Kecamatan Palu Barat adalah pengetatan pelaksanaan tata tertib sekolah.Melalui penerapan tata tertib sekolah di Sekolah D asar Bumi Bahari Kecamatan Palu Barat dapat merekonstruksi perilaku peserta didik.Perilaku yang dikonstruk tersebut adalah perilaku yang dibawanya dari keluarga mereka masing-masing yang cukup beraneka ragam berubah menjadi perilaku peserta didik yang sangat bermoral. Perilaku ini tidak begitu saja berubah, akan tetapi melalui sebuah proses penerapan tata tertib yang sangat panjang, berupa nasehat, peringatan, bimbingan secara personal, pujian, bahkan tidak jarang diberikan hukuman agar moral yang diiginkan dapat menyatu dalam diri peserta didik. Jika dicermati data yang telah dikemukakan sebelumnya, moral peserta didik yang sudah inheren dalam diri mereka muncul pada saat peserta didik duduk di bangku kelas IV.Pada saat ini kristalisasi moral sebagai dampak

${ }^{14}$ W.J.S. Poerwadarminta, Kamus Umum Bahasa Indonesia (Jakarta : Balai Pustaka, 1982) h. 254

${ }^{15}$ Departemen Pendidikan dn Kebudayaan, Pengelolaan Kelas Di Sekolah Dasar (Jakarta : Direktotat Pendidikan Dasar dan Menengah, 1993) h. 78 
pengetatan tata tertib sekolah telah terpola sedemikian rupa, sehingga peserta didik tidak lagi merasa bahwa tata tertib adalah sesuatu yang sangat menyulitkan dan memberatkan.Mereka telah terbiasa melakukan hal-hal baik bukan karena "paksaan" tata tertib, melainkan karena sudah menjadi kebutuhannya.Bahkan mereka justru malu, canggung atau merasa tidak enak jika tidak melakukan hal-hal yang sudah diajarkan sejak dulu.Dalam proses penerapan tata tertib sekolah untuk mendidik moralitas peserta didik, Sekolah Dasar Inpres Bumi Bahari Kecamatan Palu Baratmenemui beberapa hambatan, di antaranya pemahaman peserta didik terhadap tata tertib itu sendiri yang bereda-beda. Di samping itu, masih kentalnya pengaruh kebiasaan yang mereka bawa dari rumah masing-masing, sehingga tidak terbiasa dengan peraturan yang ditetapkan oleh tata tertib Sekolah Dasar Inpres Bumi Bahari Kecamatan Palu Barat. 


\section{Kesimpulan}

Penerapan tata tertib sekolah dapat merekonstruksi moralitas peserta didik, sehingga menjadi bahagian yang inheren dengan diri peserta didik itu sendiri. Dalam mendidik moralitas peserta didik melalui penegakan tata tertib sekolah, SD N Inpres Bumi Bahari menemui beberapa hambatan, di antaranya pemahaman peserta didik terhadap tata tertib dan masih kentalnya pengaruh kebiasaan yang mereka bawa dari rumah masing-masing.

Berdasarkan hasil penelitian ini, masih ditemukan adanya beberapa hambatan yang dihadapi oleh SD N Inpres Bumi Bahari, sehingga penulis menyarankan agar Kepala sekolah dan seluruh komponen sekolah untuk terus berupaya agar dapat mendisiplinkan peserta didik sesuai dengan situasi dan kondisi yang ada. Setiap komponen sekolah agar lebih menyadari bahwa watak peserta didik dan pembentukannya tidak bertumpu pada guru kelas semata-mata akan tetapi seluruh guru dan kompenen lainnya harusbersinergi untuk mewujudkan moralitas peserta didik. 


\section{Referensi}

A rikunto, Suharsimi Manajemen Penditian, Jakarta: PT. Rineka Cipta, 1998

As., Asmaran Pengantar Studi Akhlak Edisi Revisi, Cet. III ; Jakarta : Raja Grafindo Persada, 2002

D epartemen gama R.I. D irektoran Jendderal kelembagaan Agama Islam, Memahami Paradgra Baru Penddikan Nasional Dalam UndangUndang SISDIKNAS,Jakarta : D itjen Kelembagaan Agama Islam D epag, 2003

D epartemen Pendidikan dan Kebudayaan, Kams Besar Bahasa Indonssia, Cet. III ; Jakarta : Balai Pustaka, 1990

Direktotat Pendidikan D asar dan Menengah, 1993

G etteng, A. Rahman Penddikan Isam Dalam Penbangunan, Ujung Pandang : Yayasan al-Ahkam, 1997

Hasbullah, Dasar-Dasar Ilmu Pendidikan Cet. I ; Jakarta: PT. Radja Grafindo Persada. 2005

Nugroho, Novem Pendidikan Moral Menunt Jdhn lodke Pessektif Pendidkan Agama Islam (Yogyakarta : Universitas Islam Negeri Sunan Kalijaga, Skripsi, t.tp. tahun 2015)

Poerwadarminta, W.J.S. Kams Umm Bahasa IndonesiaJakarta : Balai Pustaka, 1982

Sudarman, Paryati Bdajar Efektif di Pegunan Tingg;, Cet I; Bandung, PT Remaja Rosdakarya, 2004

Tafsir, Ahmad Ilmu Penddikan dalam Pesfektif Isam Cet.II; Bandung: PT. Remaja Rosdakarya, 1994

Tim Didaktik Kurikulum IKIP Surabaya, Pengantar Didaktik Mkodik Kunikulum PBM, Cet. V ; Jakarta : PT. Raja Grafindo Persada, 1993

Zuriah.Nurul Pendidikan Moral dan Budi Peketi dalam Pespoktif PevubahanCet. II, Jakarta: Bumi Aksara, 2008 